\title{
Three Distinct Southern Blot Hybridization Patterns of HBV-DNA in the Sera of HBV Carriers
}

\author{
Miki Yamada, Motoyasu Ishit, Masahito Miura, Shuichi \\ Sato*, Atsushi Kanno $\dagger$, Hitoshi Ohori $\ddagger$ and Takayoshi \\ Tоуота \\ The Third Department of Internal Medicine, Tohoku \\ University School of Medicine, Sendai 980, *Mizusawa \\ Hospital, Mizusawa 023, †Tohoku Kousei Nenkin Hospital, \\ Sendai 980, and $\ddagger$ Sendai Municipal Institute of Public \\ Health, Sendai 980
}

\begin{abstract}
Yamada, M., Ishir, M., Miura, M., Sato, S., Kanno, A., Ohori, H. and Tоуота, T. Three Distinct Southern Blot Hybridization Patterns of HBV-DNA in the Sera of HBV Carriers. Tohoku J. Exp. Med., 1993, 170 (4), 219-228 — The molecular species of hepatitis B virus (HBV)-DNA of 44 sera taken from $25 \mathrm{HBV}$ carriers were examined by Southern blot hybridization with a biotin-labeled HBV-DNA probe and classified into three patterns. Type I consisted of two distinct bands of $4.0 \mathrm{~kb}$ and $3.2 \mathrm{~kb}$. Type II consisted of the $4.0 \mathrm{~kb}$ and $3.2 \mathrm{~kb}$ bands and a smear between these two bands. Type III showed a broad band below $4.0 \mathrm{~kb}$. With endogenous HBV-DNA polymerase reaction, the smear disappeared and $4.0 \mathrm{~kb}$ and $3.2 \mathrm{~kb}$ bands appeared. After EcoRI digestion, the 4.0 $\mathrm{kb}$ band disappeared to form a single band of $3.2 \mathrm{~kb}$. These results suggest that the $4.0 \mathrm{~kb}$ and $3.2 \mathrm{~kb}$ forms are a relaxed circular, fully double-stranded DNA and a linear, fully double-stranded DNA, respectively, and that the smear between 4.0 $\mathrm{kb}$ and $3.2 \mathrm{~kb}$ is formed from the sum of relaxed circular, partially double-stranded DNAs with various length of plus strands. Comparison between histological diagnosis and Southern blot hybridization patterns of $25 \mathrm{HBV}$ carriers indicates that these three patterns are closely related to the degree of hepatitis.

Southern blot hybridization; HBV-DNA; HBV carriers
\end{abstract}

Hepatitis B virus (HBV), or Dane particle, has a lipid envelope embedded with surface antigen proteins. Inside the lipid envelope there is a core particle, in which double-stranded HBV-DNA exists. $\mathrm{HBV}$ also contains a partially single-stranded circular DNA, which consists of a complete minus strand of approximately 3,200 bases and a plus strand of $1,700-2,800$ bases; HBV is, therefore, heterogeneous in terms of the length of the plus strand (Gerber and Thung 1985; Krogsgaard 1988).

HBV itself does not have cytopathic effect on hepatocytes, and liver cell

Received February 26, 1993; revision accepted for publication June 25, 1993. 
necrosis is caused by host immune response to viral antigen expressed on hepatocytes (Mondelli et al. 1982). Hence, increased expression of viral antigen on hepatocytes due to high HBV replication leads to marked hepatitis (Chu et al. 1985; Hsu et al. 1987). On the other hand, we examined previously the form of $\mathrm{HBV}$ in hepatocytes by electron microscopy and reported that viral particles, including Dane particle and core particle, were observed in HBV carriers without hepatitis, but not in those with active liver disease (Akiba et al. 1987). These facts suggest that the replication state of HBV may differ according to the disease activity. HBV, which replicates in hepatocytes, is secreted finally into blood as a form of Dane particle (Summers and Mason 1982). Several previous studies by Southern blot analysis on the molecular state of HBV in the sera of HBV carriers have demonstrated that HBV is heterogeneous in terms of the length of plus strand (Imazeki et al. 1984; Lok et al. 1985; Scott et al. 1985). There have been, however, no reports which assess the contribution of molecular variation of serum HBV-DNA to the disease activity.

This paper presents the results of experiments in which HBV-DNA in the sera of HBV carriers of several categories were examined by Southern blot hybridization with a biotin-labeled probe. The experiments identified three distinct patterns which may represent a different degree of hepatitis.

\section{Materials and Methods}

Serum samples and serological tests

A total of 44 sera from $25 \mathrm{HBV}$ carriers positive for hepatitis B e antigen ( $\mathrm{HBeAg}$ ) were stored at $-80^{\circ} \mathrm{C}$ until use. The carriers were categorized histologically and clinically as follows: asymptomatic carriers (ASC; $n=6$ ), those with nonspecific reactive hepatitis (NSRH; $n=3$ ), chronic persistent hepatitis (CPH; $n=4$ ), chronic active hepatitis (CAH; $n=10$ ) and liver cirrhosis (LC; $n=2)$. Hepatitis B surface antigen (HBsAg) and antibody against $\mathrm{HBsAg}$ were examined by radioimmunoassay (Abbott Laboratories, North Chicago, IL, USA), and $\mathrm{HBeAg}$ and antibody against $\mathrm{HBeAg}$ were examined by enzyme-linked immunoassay (Abbott Laboratories). HBV specific DNA polymerase activity in serum was measured according to the method of Kaplan et al. (1973).

Isolation of Dane particles

Dane particles were collected with a modified procedure described by Sattler and Robinson (1979). Briefly, $5 \mathrm{ml}$ of serum was layered on $20 \mathrm{ml}$ of $30 \%$ sucrose in buffer A (10 mM Tris- $\mathrm{HCl}, 150 \mathrm{mM} \mathrm{NaCl}, \mathrm{pH} 7.6$ ) containing $1 \mathrm{mM}$ EDTA, $1 \%$ 2-mercaptoethanol $(2 \mathrm{ME})$, and $1 \mathrm{mg} / \mathrm{ml}$ bovine serum albumin (BSA), and centrifuged at 40,000 rpm for $4 \mathrm{hr}$ at $4^{\circ} \mathrm{C}$ with a Hitachi RPS-56 rotor. The supernatant was carefully removed, and the precipitate was resuspended in $600 \mu \mathrm{l}$ of buffer A.

Extraction of DNA from serum and Dane particles

A total of $780 \mu \mathrm{l}$ of serum or $100 \mu \mathrm{l}$ of the Dane particle solution was added to buffer B (10 mM Tris-HCl, $20 \mathrm{mM}$ EDTA, $\mathrm{pH} \mathrm{7.6)} \mathrm{containing} 1 \%$ sodium dodecyl sulphate (SDS), $4 \mathrm{mg} / \mathrm{ml}$ pronase E (Sigma, St. Louis, MO, USA) and 1\%2ME. After incubation for $4 \mathrm{hr}$ at $37^{\circ} \mathrm{C}$, DNA in the solution was extracted with an equal volume of phenol and chloroform and then precipitated with 2 volumes of ethanol overnight at $-20^{\circ} \mathrm{C}$. After centrifugation at 10,000 rpm for $20 \mathrm{~min}$, the DNA pellet was dried and dissolved again in TE buffer (10 mM 
Tris-HCl, 1 mM EDTA, pH 7.6).

Endogenous $\mathrm{HBV}-\mathrm{DNA}$ polymerase reaction

Endogenous HBV-DNA polymerase reaction was performed according to the method of Sattler and Robinson (1979). One hundred microliters of the Dane particle solution was added to $50 \mu \mathrm{l}$ of a mixture containing $1 \mathrm{mM}$ dATP, $1 \mathrm{mM}$ dCTP, $1 \mathrm{mM}$ dGTP, $1 \mathrm{mM}$ dTTP (Bethesda Research Laboratories, Gaithersburg, MD, USA), $80 \mathrm{mM} \mathrm{MgCl} 2,0.2 \mathrm{M}$ Tris- $\mathrm{HCl}$ ( $\mathrm{pH} 7.6$ ), $0.24 \mathrm{M} \mathrm{NH}_{4} \mathrm{Cl}, 1 \%$ Nonidet P-40 and 0.1\% 2ME. After incubation for $3 \mathrm{hr}$ at $37^{\circ} \mathrm{C}$, DNA was extracted as described above.

\section{Labeling of HBV-DNA with biotin}

HBV-DNA cloned in pBR322 and purified by preparative electrophoresis was purchased from Clonit Corp. (Milano, Italy). Biotin-7-dATP (Bethesda Research Laboratories) was incorporated into the DNA by a nick translation method (Rigby and Dickmann 1977).

\section{Southern blot analysis of $H B V-D N A$}

The DNAs obtained from sera or Dane particles were electrophoresed through a $1 \%$ agarose gel and transferred to a nitrocellulose filter (Advantec Toyo Corp., Tokyo). The filter was dried for $3 \mathrm{hr}$ at $80^{\circ} \mathrm{C}$ and then was prehybridized in a solution containing $50 \%$ formamide, 5X SSC (1X SSC is $150 \mathrm{mM} \mathrm{NaCl}, 15 \mathrm{mM}$ sodium citrate), $5 \mathrm{X}$ Denhardt's solution (1X Denhardt's solution is $0.02 \%$ BSA, $0.02 \%$ polyvinylpyrrolidone, $0.02 \%$ Ficoll $400), 25 \mathrm{mM}$ sodium phosphate $(\mathrm{pH} 6.5)$, and $500 \mu \mathrm{g} / \mathrm{ml}$ sonicated salmon sperm DNA (Pharmacia, Uppsala, Sweden) for $4 \mathrm{hr}$ at $42^{\circ} \mathrm{C}$. The prehybridization solution was removed, and then the filter was hybridized in a solution containing $45 \%$ formamide, $5 \mathrm{X}$ SSC, 1X Denhardt's solution, $20 \mathrm{mM}$ sodium phosphate ( $\mathrm{pH} 6.5$ ), $5 \%$ dextran sulphate, and $200 \mu \mathrm{g} / \mathrm{ml}$ sonicated salmon sperm DNA for $18 \mathrm{hr}$ at $42^{\circ} \mathrm{C}$. Biotin-labeled probe was denatured by boiling for $10 \mathrm{~min}$ immediately before adding to the hybridization mixture. The filter was then washed twice in $2 \mathrm{X}$ SSC with $0.1 \%$ SDS, twice in $0.2 \mathrm{X}$ SSC with $0.1 \%$ SDS for 3 min at room temperature, and twice in $0.16 \mathrm{X}$ SSC with $0.1 \%$ SDS for $15 \mathrm{~min}$ at $50^{\circ} \mathrm{C}$, and rinced once in $2 \mathrm{X}$ SSC. After incubation in a blocking buffer $(100 \mathrm{mM}$ Tris- $\mathrm{HCl}$, $150 \mathrm{mM} \mathrm{NaCl}, 3 \% \mathrm{BSA}, \mathrm{pH} \mathrm{7.6)}$ for $1 \mathrm{hr}$ at $65^{\circ} \mathrm{C}$, the filter was incubated for $10 \mathrm{~min}$ with streptavidin-alkaline phosphatase conjugate, which was visualized with nitroblue tetrazolium and 5-bromo-4-chloro-3-indolylphosphate.

\section{HBV-DNA spot hybridization}

DNA extracted from $50 \mu 1$ of serum was dissolved in $50 \mu 1$ of TE, denatured by adding $50 \mu \mathrm{l}$ of $1 \mathrm{~N} \mathrm{NaOH}$, and incubated for 10 min at room temperature. The DNA was then neutralized with $200 \mu$ l of solution containing $0.5 \mathrm{M}$ Tris- $\mathrm{HCl}(\mathrm{pH} \mathrm{7.6)}$ and $3 \mathrm{M} \mathrm{NaCl}$. The DNA was applied to nitrocellulose filter and baked for $3 \mathrm{hr}$ at $80^{\circ} \mathrm{C}$. Hybridization and detection of HBV-DNA was performed as described above. Spot hybridization using a ${ }^{32} \mathrm{P}$-labeled probe was also performed as described in the previous paper (Kanno et al. 1987).

\section{Statistical analysis}

The Student's $t$-test was used for statistical analysis.

\section{RESUlts}

Detection of serum HBV-DNA in spot hybridization with a biotin-labeled $H B V$ DNA probe

Spot hybridization using a biotin-labeled HBV-DNA probe was performed to 
determine the concentration of serum HBV-DNA. A known concentration of HBV-DNA was diluted and used for spot hybridization. The DNA concentration was roughly correlated with the spot density in the range from 1 to $100 \mathrm{pg} / 50 \mu \mathrm{l}$ (Fig. 1). The concentration was graded from \pm to $5+$ according to the spot density. The grades, $\pm 1+, 2+, 3+, 4+$, and $5+$ corresponded to $1,2.5$ and 5 , $10,20,50$, and $100 \mathrm{pg}$ of $\mathrm{HBV}-\mathrm{DNA}$ per $50 \mu 1$, respectively.

\section{Analysis of serum $H B V-D N A$ by Southern blot hybridization}

HBV-DNAs extracted from 44 sera of HBV carriers were electrophoresed and hybridized with a cloned HBV-DNA labeled with biotin. Three different hybridization patterns were demonstrated (Fig. 2). The first was the pattern with two distinct bands of $4.0 \mathrm{~kb}$ and $3.2 \mathrm{~kb}$ (type I in Fig. 2). The second contained, in addition to the $4.0 \mathrm{~kb}$ and $3.2 \mathrm{~kb}$ bands, a smear with a light tone in density between these two bands (type II in Fig. 2). The third showed only a broad band below $4.0 \mathrm{~kb}$ (type III in Fig. 2).

To confirm that DNAs extracted from the sera were derived from Dane particles, DNAs were extracted from the Dane particles collected from each of the three types of sera showing distinctive patterns in Southern blot hybridization. Their hybridization patterns were compared with those of DNAs obtained from the original sera. The same hybridization patterns as found in the sera were obtained in Dane particles as well (data not shown). Neither the sera from 10 $\mathrm{HBV}$ carriers negative for HBV-DNA in serum nor those from 10 controls negative for all HBV markers showed any bands or stains. The same Southern blot hybridization was performed in serial twofold dilutions of HBV-DNAs showing type I and type III to see whether hybridization patterns might be affected by DNA concentration. The hybridization patterns did not change even when DNA was diluted (Fig. 3).

Dane particles were collected from the serum showing type III pattern and were subjected to the endogenous HBV-DNA polymerase reaction to characterize

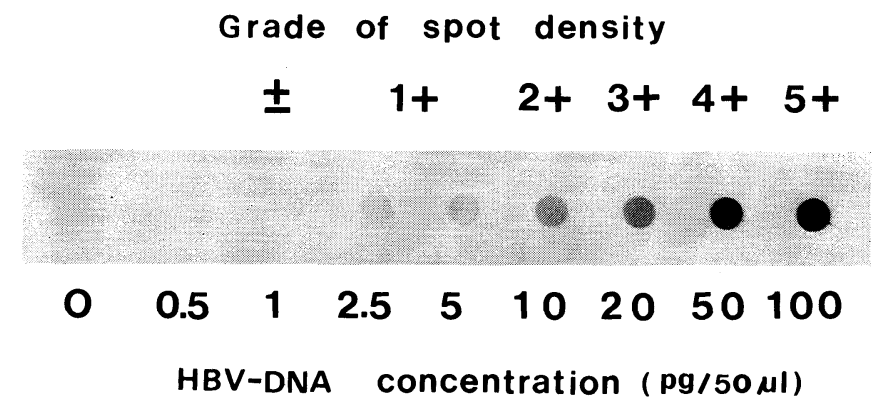

Fig. 1. Detection of serum HBV-DNA in spot hybridization with a biotin-labeled HBV-DNA probe. A known concentration of HBV-DNA was diluted and hybridized with a cloned HBV-DNA labeled with biotin. 


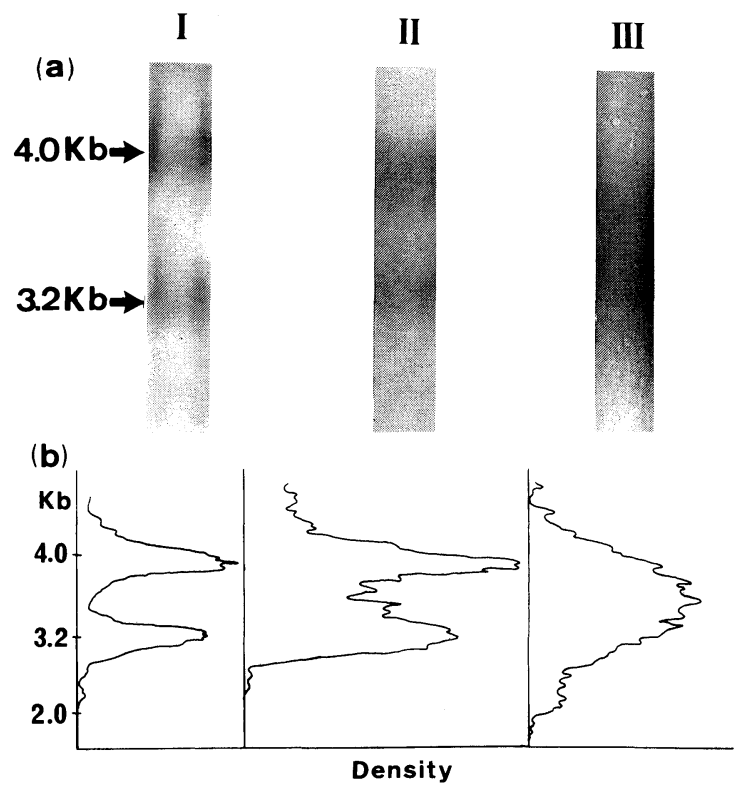

Fig. 2. Three typical Southern blot hybridization patterns of serum HBV-DNA (a) and their densitograms (b). The DNAs were electrophoresed through a $1 \%$ agarose gel, blotted onto nitrocellulose filter, and hybridized with a cloned HBV-DNA labeled with biotin. I, II and III indicate type I, type II and type III, respectively.

A

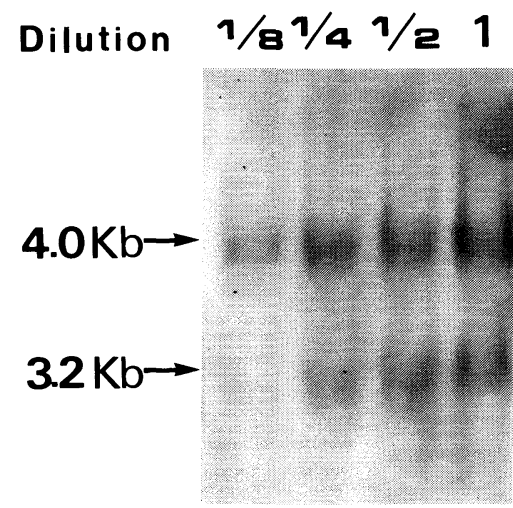

B

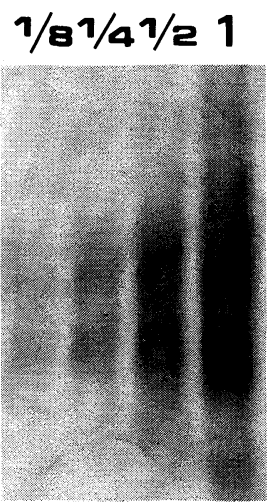

Fig. 3. Effect of dilution of HBV-DNA on Southern blot hybridization pattern. HBV-DNAs of type I (A) and type III (B) were subjected to serial twofold dilution, and then to Southern blot hybridization using a biotin-labeled probe. 
the broad band below $4.0 \mathrm{~kb}$. After this polymerase reaction, a broad band below $4.0 \mathrm{~kb}$ (Lane 2 in Fig. 4) disappeared and two bands of $4.0 \mathrm{~kb}$ and $3.2 \mathrm{~kb}$ appeared (Lane 3 in Fig. 4). When these HBV-DNAs of $4.0 \mathrm{~kb}$ and $3.2 \mathrm{~kb}$ were digested with EcoRI, which cut one site within the HBV-DNA used here, the $4.0 \mathrm{~kb}$ band disappeared and the $3.2 \mathrm{~kb}$ band became denser (Lane 4 in Fig. 4).

Relationship between the concentration of $H B V-D N A$ and the levels of $H B V$ specific DNA polymerase activity

HBV specific DNA polymerase activity and the concentration of HBV-DNA in 44 sera which were classified into three types (15 sera of type I, 15 of type II and 14 of type III) were simultaneously measured, since the smear between $4.0 \mathrm{~kb}$ and $3.2 \mathrm{~kb}$ was thought to be the sum of relaxed circular, partially doublestranded HBV-DNAs with incomplete strands. The concentration of HBV-DNA was graded by the spot density by spot hybridization with a biotin-labeled probe in comparison to the standard as shown in Fig. 1. In each grade of HBV-DNA concentration, HBV specific DNA polymerase activity was found to be highest in type III and lowest in type I (Fig. 5).

Pathological diagnosis and Southern blot patterns of serum $H B V-D N A$

A total of $25 \mathrm{HBV}$ carriers who were histologically and clinically categorized were enrolled for analyzing their serum HBV-DNAs. As seen in Table 1, $9(69.2 \%)$ of 13 patients who showed type I were HBV carriers with absent or

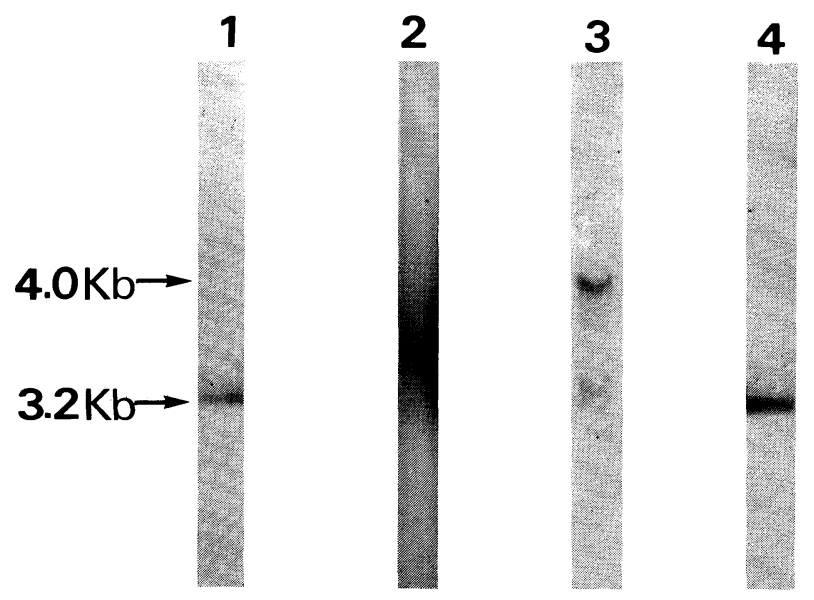

Fig. 4. Endogenous polymerase reaction of HBV in type III. DNA was extracted from Dane particles in the serum of type III, treated as indicated below, and analyzed by Southern blot hybridization. Lane 1, cloned HBV-DNA (fully double-stranded linear HBV-DNA) as a $3.2 \mathrm{~kb}$ marker; Lane 2, DNA extracted from Dane particles; Lane 3, DNA extracted from Dane particles after endogenous HBV-DNA polymerase reaction; Lane 4, DNA digested by EcoRI after endogenous HBV-DNA polymerase reaction. 


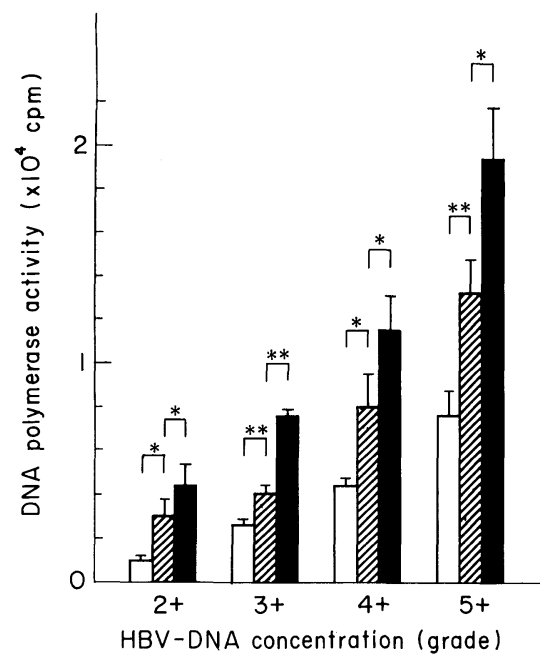

Fig. 5. The concentration of HBV-DNA and the levels of HBV specific DNA polymerase activity in 44 sera of $\mathrm{HBV}$ carriers. The concentration of HBV-DNA in each serum was graded from $2+$ to $5+$ according to the spot density as shown in Fig. $1 .{ }^{*}$ and $* *$ indicate $p<0.05$ and $p<0.01$, respectively. Bars represent mean \pm standard deviation. $\square$, type I; $\succcurlyeq$, type II ; $\square$, type III.

TABLE 1. Pathological diagnosis and Southern blot patterns of serum HBV-DNA

\begin{tabular}{ccccccc}
\hline \multirow{2}{*}{ Type } & \multirow{2}{*}{$\begin{array}{c}\text { Number } \\
\text { tested }\end{array}$} & \multicolumn{5}{c}{ Pathological diagnosis } \\
\cline { 3 - 6 } & & ASC $^{\text {a }}$ & NSRH & CPH & CAH & LC \\
\hline I & 13 & 6 & 3 & 2 & 1 & 1 \\
II & 9 & 0 & 0 & 2 & 6 & 1 \\
III & 3 & 0 & 0 & 0 & 3 & 0 \\
\hline
\end{tabular}

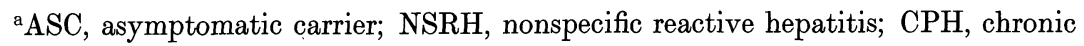
persistent hepatitis; $\mathrm{CAH}$, chronic active hepatitis; LC, liver cirrhosis.

minimal hepatitis including ASC and NSRH. On the other hand, all patients who showed type II or type III were HBV carriers with hepatitis including CPH, $\mathrm{CAH}$, and LC.

\section{Discussion}

In the present study, a biotin-labeled HBV-DNA probe was used to identify three distinct patterns of Southern blot which had not been reported previously. Many laboratories, however, use a ${ }^{32} \mathrm{P}$-labeled probe for Southern blot analysis of HBV-DNA (Imazeki et al. 1984; Lok et al. 1985; Scott et al. 1985; Carloni et al. 1987). We also analyzed HBV-DNA by Southern blot hybridization with a ${ }^{32} \mathrm{P}$-labeled probe, but failed to discriminate between these three patterns in 


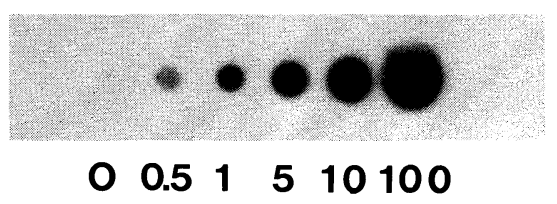

\section{HBV-DNA (pg/50 $\mathrm{\mu l})$}

Fig. 6. Spot hybridization of serum HBV-DNA with a ${ }^{32} \mathrm{P}$-labeled HBV-DNA probe.

autoradiography. In spot hybridization using a ${ }^{32} \mathrm{P}$-labeled probe, the concentration of HBV-DNA correlated with spot size but not with spot density (Fig. 6). Since the bands became broader with the increase of DNA concentration in Southern blot hybridization as well, it was difficult to evaluate the smear between $4.0 \mathrm{~kb}$ and $3.2 \mathrm{~kb}$ when HBV-DNA at a high concentration was hybridized to ${ }^{32} \mathrm{P}$-labeled probe. By contrast, with a biotin-labeled probe, bands became denser as the concentration of HBV-DNA increased. This was supported by the finding that the bands patterns in Southern blot hybridization with a biotin-labeled probe did not change irrespective of HBV-DNA concentration of serum samples (Fig. 3).

Endogenous HBV-DNA polymerase reaction converts incomplete to complete strands. After this reaction, the smear between $4.0 \mathrm{~kb}$ and $3.2 \mathrm{~kb}$ disappeared and two bands of $4.0 \mathrm{~kb}$ and $3.2 \mathrm{~kb}$ newly appeared. The concentration of HBV-DNA by spot hybridization and $\mathrm{HBV}$ specific DNA polymerase activity were also measured. Spot hybridization represents the amount of viral genomes, and DNA polymerase activity depends on both the amount of viral genomes and the length of incomplete strand (Robinson 1975; Santantonio et al. 1990). Dane particles containing HBV-DNAs with the smear between $4.0 \mathrm{~kb}$ and $3.2 \mathrm{~kb}$ had higher DNA polymerase activities than those containing HBV-DNAs without the smear (Fig. 5). These results suggest that the smear represents the incomplete HBV-DNAs. These incomplete DNAs are thought to be various lengths of plus strands, since a plus strand is synthesized after complete minus strand synthesis (Summers and Mason 1982; Gerber and Thung 1985; Scott et al. 1985). We speculate accordingly that the smear is relaxed circular, double-stranded HBV-DNAs with various length of incomplete plus strands. With EcoRI digestion, the $4.0 \mathrm{~kb}$ band disappeared and the $3.2 \mathrm{~kb}$ band became denser, indicating that $4.0 \mathrm{~kb} \mathrm{HBV}-\mathrm{DNA}$ is a relaxed circular, fully double-stranded DNA, and $3.2 \mathrm{~kb} \mathrm{HBV-DNA}$ is a linear, fully double-stranded one.

In this study, type I was observed mainly in HBV carriers without hepatitis, while type II and type III were observed in those with hepatitis. This result suggests that serum HBVs differ at molecular level according to the disease activity. However, since nothing is known about how the molecular state of serum HBV-DNA contributes to the induction of hepatitis, clinical implication of these three types is still speculative, and further studies are necessary to make a 
conclusion.

\section{Acknowledgment}

We thank Professor K. Sugamura and his colleagues, Department of Bacteriology, Tohoku University School of Medicine, for their technical support.

\section{References}

1) Akiba, T., Nakayama, H., Miyazaki, Y., Kanno, A., Ishii, M. \& Ohori, H. (1987) Relationship between the replication of hepatitis B virus and the localization of virus nucleocapsid antigen $(\mathrm{HBcAg})$ in hepatocytes. J. Gen. Virol., 68, 871-877.

2) Carloni, G., Colloca, S., Delfini, C., Manzin, A., Clementi, M. \& Galibert, F. (1987) Detection of HBV infectivity by spot hybridization in HBeAg-negative chronic carriers: HBV DNA in sera from asymptomatic and symptomatic subjects. J. Med. Virol., 21, 15-23.

3) Chu, C.M., Karayiannis, P., Fowler, M.J.F., Monjardino, J., Liaw, Y.F. \& Thomas, H.C. (1985) Natural history of chronic hepatitis B virus infection in Taiwan; Studies of hepatitis B virus DNA in serum. Hepatology, 5, 431-434.

4) Gerber, M.A. \& Thung, S. (1985) Biology of disease; Molecular and cellular pathology of hepatitis B. Lab. Invest., 52, 572-590.

5) Hsu, H.C., Su, I.J., Lai, M.Y., Chen, D.S., Chang, M.H., Chung, M.H. \& Sung, J.L. (1987) Biologic and prognostic significance of hepatocyte hepatitis B core antigen expressions in the natural course of chronic hepatitis B virus infection. J. Hepatol., 5, $45-50$.

6) Imazeki, F., Omata, M., Yokosuka, O., Matsuyama, Y., Ito, Y., Uchiumi, K., Mori, J., Tanaka, A., Hirota, K., Tagawa, M. \& Okuda, K. (1984) Analysis of hepatitis B virus DNA in the liver and serum by Southern blot hybridization. Acta Hepatol. $J p n ., 25,855-858$. (in Japanese with English abstract)

7) Kanno, A., Ohori, H., Matsuda, K., Nakayama, H., Miyazaki, Y., Ishii, M., Suzuki, H., Ohtsuki, M. \& Goto, Y. (1987) Virological significance of HBeAg subtypes (HBeAg/ 1 and $\mathrm{HBeAg} / 2)$ in patients with type B hepatitis. Hepatology, 7, 15-19.

8) Kaplan, P.M., Greenman, R.L., Gerin, J.L., Purcell, R.H. \& Robinson, W.S. (1973) DNA polymerase associated with human hepatitis B antigen. J. Virol., 12, 995-1005.

9) Krogsgaard, K. (1988) Hepatitis B virus DNA in serum; Applied molecular biology in the evaluation of hepatitis B infection. Liver, 8, 257-283.

10) Lok, A.S.F., Karayiannis, P., Jowett, T.P., Fowler, M.J.F., Farci, P., Monjardino, J. \& Thomas, H.C. (1985) Studies of HBV replication during acute hepatitis followed by recovery and acute hepatitis progressing to chronic disease. J. Hepatol., 1, 671679 .

11) Mondelli, M., Vergani, G.M., Alberti, A., Vergani, D., Portmann, B., Eddlestone, A.L.W.F. \& Williams, R. (1982) Specificity of lymphocyte cytotoxicity to autologous hepatocytes in chronic hepatitis B virus infection: Evidence that $\mathrm{T}$ cell are directed against HBV core antigen expressed on hepatocytes. J. Immunol., 129, 2773-2778.

12) Rigby, P.W.J. \& Dickmann, M. (1977) Labelling of deoxyribonucleic acid to high specific activity in vitro by nick translation with DNA polymerase I. J. Mol. Biol., 113, 237-251.

13) Robinson, W.S. (1975) DNA and DNA polymerase in the core of the Dane particle of hepatitis B. Am. J. Med., 270, 151-159.

14) Santantonio, T., Pontiso, P., Milella, M., Chemello, L., Luchena, N. \& Pastore, G. (1990) Detection of hepatitis B virus DNA in serum by spot hybridization technique: Sensitivity and specificity of radiolabeled and biotinlabeled probes. Res. Clin. Lab., 
20, 29-35.

15) Sattler, F. \& Robinson, W.S. (1979) Hepatitis B virus DNA molecules have cohesive ends. J. Virol., 32, 226-233.

16) Scott, J., Hadchouel, M., Wain-Hobson, S., Sonigo, P., Courouce, A.M., Tiollais, P. \& Brechot, C. (1985) Hepatitis B virus DNA in Dane particles: Evidence for the presence of replicative intermediates. J. Infect. Dis., 151, 610-617.

17) Summers, J. \& Mason, W. (1982) Replication of the genome of a hepatitis B like virus by reverse transcription of an RNA intermediate. Cell, 29, 403-415. 